\title{
The Association between Nurse Characteristics, Supervision, and Nurse Compliance at Madani Hospital in Medan, North Sumatera
}

\author{
Astri Nurhandini'), Zulfendri²), Taufik Ashar3) \\ 1)Department of Hospital Administration, Universitas Sumatera Utara \\ 2)Department of Health Policy and Administration, Universitas Sumatera Utara \\ 3)Department Environmental Health, Universitas Sumatera Utara
}

\begin{abstract}
Background: The disease pain scale related to the health service in Madani Hospital was more than $1.5 \%$ in 2017 . Nurse compliance with standard precaution has been proved to reduce the incidence of diseases related to health services. This study aimed to analyze characteristics and normative, formative and restorative supervision which influence the level of nurse compliance with standard precaution.

Subjects and Method: This was an analytic observational study with a cross-sectional design. The study was conducted at Madani hospital in Medan, North Sumatera. A sample of 89 nurses in inpatient wards was selected by total sampling. The dependent variable was nurse compliance. The independent variables were nurse characteristics, normative, formative, and restorative supervisions. The data were collected by questionnaire and analyzed by a multiple logistic regression.

Results: The level of nurse compliance with standar precaution was good (66.3\%). Nurse compliance with standar precaution increased with gender $(\mathrm{OR}=4.71 ; 95 \% \mathrm{CI}=1.14$ to $19.85 ; \mathrm{p}=$ 0.032), normative supervision $(\mathrm{OR}=6.00 ; 95 \% \mathrm{CI}=19.74$ to $1.83 ; \mathrm{p}=0.001)$, and restorative supervision $(\mathrm{OR}=25.23 ; 95 \% \mathrm{CI}=2.90$ to $219.35 ; \mathrm{p}=0.001)$.

Conclusion: Gender and the implementation of normative and restorative supervision will increase the level of nurse compliance with standard precaution.
\end{abstract}

Keywords: Nurses compliance, normative, formative, restorative supervision

\section{Correspondence:}

Astri Nurhandini. Department of Hospital Administration, Universitas Sumatera Utara. Email: nurhandiniastri@gmail.com. Mobile: 08116099983.$$
\text { BACKGROUND }
$$

Hospital is a public health service unit that continues to strive to improve quality to serve the community. One such effort is to employ qualified human resources and improve quality to serve the community. In addition to providing satisfaction and comfort for patients, improving quality is also based on the awareness of high risks in hospital activities. The spread of infection in hospitals is one of the high risks to date. Infection related to health services or Healthcare-associated Infections (HAIs) is one of the health problems in various
\end{abstract}

countries in the world, including Indonesia. In the forum of the Asian Pacific Economic Committee (APEC) or the Global Health Security Agenda (GHSA), infectious diseases related to health services have become the agenda discussed. HAIs are infections that occur in patients during treatment in hospitals or other health care facilities. This can occur when there is no infection and not in the incubation period, including infection in the hospital, but appears after the patient returns home, as well as infection due to employment of hospital staff and health workers related to the health 
service process in health care facilities (Ministry of Health of Indonesia, 2017).

In this time, the prevalence of HAIs in developed countries varied from $3.5 \%$ to 12\%. The European Centers for Diseases Control reports the average prevalence in European countries is $7.1 \%$. The agency said there were an estimated 4,131,000 patients exposed to at least 4,544,100 cases of HAIs each year in Europe. The prevalence of HAIs is in the range of $5.7 \%$ and $19.1 \%$ in countries with low and medium income per capita (World Health Organization, 2011). In Indonesia, the case of HAIs is still the main cause of death, illness in hospitals, and other health care facilities (Herpan, 2012). According to the 2017 Directorate General, Indonesian Health Services obtained a figure of 6 to $6 \%$ with an average of $9.8 \%$ taken from 10 Education General Hospitals which held active surveillance. The case of HAIs in Medan also occurred and was known by the existence of the ILO in Dr. Pringadi hospital from June to December 2015 was recorded at $20.39 \%$. Peripheral vascular disease was 9.62\% (Octavia, 2016) in the ICU room, $1.5 \%$ in the central surgery installation room, and $8.1 \%$ in the NICU room. Meanwhile, according to the Decree of Minister of Health of The Republic of Indonesia (2008), minimum service standards are for indicators of nosocomial infection. As one of the private hospitals in Medan, the incidence of infection in Madani general hospital during the period of September 2017 was recorded at $1.6 \%$ in the IDO case. Whereas in the case of $1.5 \%$ Phelebitis in the hospital is $\leq 51.5 \%$, so it can be concluded that the incidence of nosocomial infections in Madani general hospital is high.

According to the Indonesian Ministry of Health (2017), the incidence of HAIs can actually be prevented if health service facilities consistently implement prevention and control programs. Programs that include infection prevention and control are infection prevention and control measures. The infection prevention and control program is carried out by breaking the cycle of infectious disease transmission through standard and transmission-based precaution (Ministry of Health of Republic of Indonesia, 2017).

The quality of health services, especially nursing in hospitals can be assessed through various indicators. One indicator is an assessment of infection prevention and control efforts. Nurses are responsible for maintaining the safety of patients in hospitals through prevention of accidents, injuries, or other trauma, and through preventing the spread of infections (Handiyani, 2004). Nurses who work in hospitals have different characteristics and are very diverse both in education, age, working period, and level of knowledge. According to Morais (2015), certain sociodemographic variables such as age, gender, occupational category, marital status, work location in the hospital, and work experience were found to be related to compliance with standard precaution. Morais (2015) stated that $78 \%$ of subjects reported using standard precaution when caring for patients.

Nurse compliance can be increased through supplementation. One of them is nursing supervision which is an ongoing supervision and coaching activity that includes nursing services, workforce problems, and equipment, so that patients get quality services (Nursalam, 2011). Supervisor support builds more positive association with their subordinates and encourages more open and informal communication that leads to higher levels of safety and compliance commitments among employees (Glendon, 2016). A study by Abdullah et al. (2012), stated that in the 
inpatient installation of Haji Makassar hospital there was a significant association between the supervision of the head of the room and the compliance of nursing staff.

Given the importance of the role of nurses in preventing infection and the high rate of infection in Madani general hospital in Medan in 2017, the researchers were interested in examining the association of individual characteristics and supervision of nurses' compliance to the application of standard precaution at the Madani general hospital in 2018.

\section{SUBJECTS AND METHOD \\ 1. Study design \\ This study was a cross sectional study conducted at Madani general hospital in Medan, North Sumatra.}

\section{Population and sample}

The populations in this study were 89 inpatient nurses at the Madani general hospital in Medan. The sample used was the entire population.

\section{Study Variables}

The dependent variable was the compliance of nurses. Independent variables were the characteristics of nurses and supervision.

\section{Operational definition of variables}

Nurse compliance was the behavior of nurses as a professional on a recommendation, procedure, or regulation that must be done or adhered to.

Supervision was an activity that guides, moves, observes, plans, and evaluates continuously with members as a whole in accordance with the abilities and limitations possessed by members.

Standard precaution namely primary precaution, were designed to be applied routinely in the care of all patients in hospitals and other health care facilities, whether diagnosed, suspected to be infected or colonized. It was applied to prevent cross transmission before the patient was diagnosed, before the results of laboratory tests and after the patient was diagnosed. Health workers such as laboratory staff, households, CSSD, garbage disposal and others were also at high risk of being infected.

\section{Study Instruments}

The tool for measuring nurse compliance that had been tested for validity and reliability was Compliance with Standard Precaution Scale (CSPS), which were 20 statements. Questionnaires were developed by Lam (2017). The CSPS dimension was grouped according to the Standard Precaution guidelines and general understanding, namely:

(1) The Use of Personal Protective Equipment; (2) The Use of Sharp Objects; (3) Waste Disposal; (4) Decontamination; (5) Prevention of Cross Infection..

The tool for measuring nursing service supervision that had been tested for validity and reliability was The Manchester Clinical Supervision Scale by White and Wainstanley (2011) which was divided into three components which were the development of the proctor model, namely normative, formative, and restorative. It used the Guttman Scale with 26 statements.

\section{Data analysis}

The data were analyzed by a multiple logistic regressions.

\footnotetext{
RESULTS

The association of the characteristics of nurse compliance is shown in Table 1. Based on gender, it was shown that male nurses generally had a high level of nurse compliance on good standard precaution (84.6\%), while female nurses had more with the level of nurse compliance was good standard precaution (58.7\%). In the Chisquare statistical test, the value of $p=0.019$ was obtained so that it showed a significant association between the gender and the
} 
Journal of Health Policy and Management (2019), 4(3): 170-175

https://doi.org/10.26911/thejhpm.2019.04.03.04

level of nurse compliance with standard precaution.

Marital status indicated that married nurses had better level of com-

Table 1. The association between characteristics of nurse compliance with standard precaution

\begin{tabular}{|c|c|c|c|c|c|c|}
\hline \multirow{3}{*}{ Supervision } & \multicolumn{4}{|c|}{ Compliance } & & \multirow{3}{*}{$\mathbf{p}$} \\
\hline & \multicolumn{2}{|c|}{ Poor } & \multicolumn{2}{|c|}{ Good } & & \\
\hline & $\mathbf{n}$ & $\%$ & $\overline{\mathbf{n}}$ & $\%$ & & \\
\hline \multicolumn{7}{|l|}{ Gender } \\
\hline Male & 4 & 15.4 & 22 & 84.6 & 3.87 & 0.019 \\
\hline Female & 26 & 41.3 & 37 & 58.7 & & \\
\hline \multicolumn{7}{|l|}{ Marital Status } \\
\hline Married & 11 & 47.8 & 12 & 52.2 & 0.44 & 0.096 \\
\hline Single & 19 & 28.8 & 47 & 71.2 & & \\
\hline \multicolumn{7}{|l|}{ Age } \\
\hline 20-30 years & 27 & 31.8 & 58 & 68.2 & 0.44 & 0.074 \\
\hline \multirow{2}{*}{\multicolumn{7}{|c|}{ Work period }} \\
\hline & & & & & & \\
\hline$<3$ years & 26 & 33.3 & 52 & 66.7 & 0.88 & 0.842 \\
\hline$\geq 3$ years & 4 & 36.4 & 7 & 63.6 & & \\
\hline
\end{tabular}

Based on age group, most nurses aged 20 to 30 years had a good level of nurse compliance (69.1\%), while nurses who had poor standard precaution were $62.5 \%$.

Nurse with tenure less than or equal to 1 year mostly had a good level of compliance (57.1\%), while nurses with tenure $>1-2$ years had good level of nurse compliance (75\%). pliance on standard precaution (52.2\%), while unmarried nurses, most of whom had a good level of level of compliance to nurses on standard precaution (71.2\%).

Table 2. The association between supervision and nurse compliance

\begin{tabular}{|c|c|c|c|c|c|c|}
\hline \multirow{2}{*}{ Supervision } & \multicolumn{4}{|c|}{ Nurse Compliance } & \multirow{3}{*}{$\mathbf{O R}$} & \multirow{2}{*}{$\mathbf{p}$} \\
\hline & \multicolumn{2}{|c|}{ Poor } & \multicolumn{2}{|c|}{ Good } & & \\
\hline Normative & $\mathbf{n}$ & $\%$ & $\mathbf{n}$ & $\%$ & & \\
\hline Poor & 25 & 55.6 & 20 & 44.4 & 9.75 & $<0.001$ \\
\hline Good & 5 & 11.4 & 39 & 88.6 & & \\
\hline Formative & & & & & & \\
\hline Poor & 2 & 66.7 & 1 & 33.3 & 4.14 & 0.149 \\
\hline Good & 28 & 32.6 & 58 & 67.4 & & \\
\hline Restorative & & & & & & \\
\hline Poor & 13 & 93.9 & 1 & 7.1 & 44.35 & 0.026 \\
\hline Good & 17 & 22.7 & 58 & 77.3 & & \\
\hline
\end{tabular}

Table 3 showed the results of multiple logistic regression. Table 3 showed that male nurse $(b=1.63 ; \mathrm{SE}=0.79 ; \mathrm{p}=0.040)$, age $>35$ years old $(b=2.39 ; \mathrm{SE}=1.50 ; \mathrm{p}=$
Table 2 showed the association between supervision with compliance on standard precaution. Table 2 showed that good supervision $(\mathrm{OR}=9.75 ; \mathrm{p}<0.001)$, formative supervision $(\mathrm{OR}=4.14 ; \mathrm{p}=$ $0.149)$, and restorative supervision $(\mathrm{OR}=$ 44.35; $\mathrm{p}=0.026$ ) increased nurse compliance. 
precaution in hospitals and statistically significant.

Married nurse $(b=-0.06 ; \mathrm{SE}=0.93$; $\mathrm{p}=0.946$ ) decreased nurse compliance, but it was statistically non-significant.
Based on the results of multiple logistic regression analysis, the variable restorative supervision was the most dominant variable affecting the level of nurse compliance in Madani general hospital, Medan.

Table 3. The results of multiple logistic regression

\begin{tabular}{lccc}
\hline Variable & b & SE & p \\
\hline Gender (male) & 1.63 & 0.79 & 0.040 \\
Age (>35 years) & 2.39 & 1.50 & 0.111 \\
Marital status (married) & -0.06 & 0.93 & 0.946 \\
Working period (>3 years) & 0.44 & 0.97 & 0.649 \\
Normative supervision (strong) & 2.12 & 0.70 & 0.002 \\
Formative supervision (strong) & 1.23 & 1.54 & 0.427 \\
Restorative supervision (strong) & 2.88 & 1.23 & 0.019 \\
Constanta & -6.53 & 2.48 & 0.008 \\
Nagelkarke $\mathrm{R}^{2}=55.7 \%$ & & & \\
\hline
\end{tabular}

\section{DISCUSSION}

1. The association $\begin{gathered}\text { between } \\ \text { characteristics }\end{gathered}$
$\begin{aligned} & \text { and } \\ & \text { compliance }\end{aligned}$

The results of this study found that male nurses generally had a good level of nurse compliance (84.6\%) on standard precaution, whereas female nurses had a hinger number of good level of nurse compliance (58.7\%) on standard precaution. There is a significant association between genders with the level of nurse compliance on standard precaution. The results of interviews of researchers with several male nurses at Madani Hospital revealed that they were more focused on work and had the desire to do the best work due to high expectations in career advancement at work.

\section{The association between supervi- sion and nurse compliance}

The results showed that good supervision was generally at the level of nurse compliance with good standard precaution by 88.6\% and statistically showed a significant association between normative supervision and the level of nurse compliance with standard precaution. This shows that good supervision activities will increase nurse compliance with standard precaution.

The results showed that the highest percentage of nurse compliance on standard precaution was about immediately cleaning up blood spills or other body fluids with disinfectants (91\%), followed by replacing the gloves every time the patient changed (85.4\%) and placing sharp objects that had been used into special sharp objects $(89.9 \%)$ while those less than or equal to $50 \%$ were about only wearing a surgical mask or added with goggle glasses, face shields and aprons if there is a possibility of sparks (50.6\%) and only uses water when washing hands ( 49.4\%). In general, the level of nurse compliance on standard precaution shows that most of them are in the good category (66.3\%).

The results of the multivariate analysis found that the factors that influence the level of nurse compliance on standard precaution are gender, normative supervision and restorative supervision. The most dominant factor is restorative supervision $(b=17.72)$. This can be explained that this component relates to the ability to provide security for staff to be open in expressing 
feelings and problems faced, experience in practice and learning, preventing stress, coping with conflicts, giving support to staff, the process of interaction, and increase self awareness.

The results of the conclusions above state that if normative and restorative supervision is carried out properly it can increase the level of nurse compliance with standard precaution by $97 \%$.

\section{AUTHOR CONTRIBUTIONS}

Astri Nurhandini was the main researcher who collected the data and wrote the articles. Zulfendri analyzed the data, interpreted the results of the analysis. Taufik Ashar gave input on discussion and revision material.

\section{CONFLICT OF INTEREST}

There was no conflict of interest.

\section{FUNDING DAN SPONSORSHP}

The funding of this study was from the researcher independent funds so that there was no interest of other parties or agencies.

\section{ACKNOWLEDGEMENT}

I give my gratitude to the Director of the Medan General Hospital who had given permission to us to conduct a study.

\section{REFERENCES}

Clarke S, Glendon AI (2015). Human Safety and Risk Management: A Psychological Perspective. 3 edn, CRC Press, Inc., Boca Raton, FL, USA.

Handiyani $\mathrm{H}$, Allenidekania, Eryando $\mathrm{T}$ (2004). Hubungan peran dan fungsi manajemen kepala ruangan dengan keberhasilan pelaksanaan program pengendalian infeksi nosokomial. Jurnal Keperawatan Indonesia. 8(2): 54-61. http://dx.doi.org/10.7454/jki.v8i2.148.

Herpan, Wardani Y (2013). Analisis kinerja perawat dalam pengendalian infeksi nosokomial di RSU PKU Muhammadiyah Bantul Yogyakarta. Jurnal Kesehatan Masyarakat. 6(3): 175-189. http://dx.doi.org/10.12928/kesmas.v6i3.1053

Kemenkes no. 411, 2010. peraturanmenteri-kesehatan-nomor-411-tahun2010-tentang-laboratorium-klinik.pdf Kustoro BD (2010). Pengaruh kekohesifan, gaya kepemimpinan dan budaya kerja terhadap efektivitas organisasi. Jurnal Pendidikan dan Kebudayaan 16, 325. doi:10.24832/jpnk.v16i3.465

Lam SC (2017). Compliance with Standard Precautions Scale (CSPS): Fact sheet. Research Gate. doi: 10.13140/RG.2.2.25361.43363 .

Nursalam (2011). Manajemen Keperawatan: Aplikasi dalam Praktik Keperawatan Profesional Edisi 3. Salemba Medika, Jakarta.

Piai-Morais TH, Orlandi FS, de Figueiredo RM (2015). Factors influencing adherence to standard precautions among nursing professionals in psychiatric hospitals. Revista da Escola de Enfermagem. 49(3): 473-48o doi: 10.1590/Soo80623420150000300016.

World Health Organization (2017). The burden of health care-associated infection worldwide. 